\title{
ARTIKELEN
}

\section{De relatie tussen werkeisen, energiebronnen, spanning en werkplezier: een kwestie van leeftijd?}

Bert Schreurs, Anja Van den Broeck, Guy Notelaers, Beate van der Heijden \& Hans De Witte

\section{Inleiding}

Mensen leven steeds langer, en in tamelijk goede gezondheid. We werken echter onvoldoende lang om de kosten van de recente demografische ontgroening en vergrijzing te dragen (zie ook Schultz \& Adams, 2007). Dit geldt zeker in België waar de werkzaamheidsgraad 62,4 percent bedraagt, waarvan 23,7 percent in deeltijd (ter vergelijking 71,5 in Nederland, maar waarvan 48,3 percent in deeltijd). Dit relatief lage cijfer is vooral te wijten aan de lage participatie van de oudste groepen werknemers: slechts 34,5 percent van de Belgen tussen 55 en 64 jaar is nog actief op de arbeidsmarkt (voor Nederland 46 percent) (Bron: Eurostat, 2010).

Om het pensioen- en zorgstelsel te kunnen garanderen gaan er in België, Nederland en andere West-Europese landen steeds luidere stemmen op om, naast een activeringsbeleid en maatregelen om vervroegd pensioen te ontmoedigen, ook de officiële pensioenleeftijd te verhogen (Voka-Kenniscentrum, 2009). De kans wordt dus reëel dat het percentage ouderen op de arbeidsmarkt stijgt. Om dit mogelijk te maken voeren heel wat organisaties tegenwoordig een leeftijdsbewust Human Resource (HR) beleid om een werkomgeving te creëren die tegemoet komt aan de specifieke behoeften van oudere werknemers (zie ook Kooij, Jansen, Dikkers \& De Lange, 2010). De werkomgeving is immers in hoge mate bepalend voor het welbevinden van werknemers, en blijkt bovendien een belangrijke factor in de beslissing van ouderen om te (blijven) werken (Schultz, Morton \& Weckerle, 1998).

Deze bijdrage wil ingaan op de vraag in hoeverre een leeftijdsbewust personeelsbeleid noodzakelijk is door twee centrale onderzoeksvragen te beantwoorden: ten eerste willen we nagaan of oudere, jongere en de middengroep van werknemers verschillen in de mate waarin ze bepaalde werkkenmerken rapporteren (d.w.z.

* Bert Schreurs is verbonden aan Maastricht University School of Business and Economics, Tongersestraat 53, Postbus 616, 6200 MD Maastricht, Nederland, tel: +31 4338 83776, e-mail: b.schreurs@maastrichtuniversity.nl. Anja Van den Broeck is verbonden aan de HogeschoolUniversiteit Brussel, België, en aan de Katholieke Universiteit Leuven, België. Guy Notelaers is verbonden aan Maastricht University School of Business and Economics. Beate Van der Heijden is verbonden aan de Radboud Universiteit, Institute for Management. Hans De Witte is verbonden aan de Katholieke Universiteit Leuven, België. 
Bert Schreurs, Anja Van den Broeck, Guy Notelaers, Beate van der Heijden \& Hans De Witte

werktempo/hoeveelheid, rolconflict, veranderingen in het werk, sociale steun en autonomie). Uit de literatuur blijkt dat bepaalde kenmerken in verschillende mate beschrijvend zijn voor het werk van werknemers van verschillende leeftijden (Van der Heijden, 2006; Van der Heijden, De Lange, Demerouti \& Van der Heijde, 2009), maar meer onderzoek is nodig om de richting van de verschillen in werkkenmerken te bepalen. Ten tweede is het vooralsnog niet duidelijk wat het belang is van deze verschillen in relatie tot werkuitkomsten, anders gezegd, of en welke verschillen in werkkenmerken cruciaal zijn voor het welzijn van werknemers van verschillende leeftijden. Daarom willen we ten tweede nagaan of de ene leeftijdsgroep meer lijdt onder, dan wel profiteert van, bepaalde werkkenmerken dan de andere leeftijdsgroep.

Ondanks de verreikende veranderingen in de samenstelling van de beroepsbevolking en het toenemende belang van een leeftijdsbewust HR-beleid, zijn dergelijke mogelijke verschillen, en de potentiële invloed ervan op werkuitkomsten nog maar zelden empirisch onderzocht (Beehr, Glazer, Nielson \& Farmer, 2000; voor een uitzondering zie De Lange, Taris, Jansen, Kompier, Houtman \& Bongers, 2005, 2010; De Lange, Taris, Jansen, Smulders, Houtman \& Kompier, 2006). In de meeste studies naar werkbeleving werd leeftijd bijvoorbeeld enkel als controlevariabele meegenomen (Schalk, Van Veldhoven, De Lange, De Witte, Kraus, Stamov-Rossnagel et al., 2010). Deze studie bouwt voort op studies van De Lange en collega's (De Lange et al., 2005, 2006, 2010), maar maakt gebruik van een grote heterogene steekproef. Dit stelt ons in staat om een duidelijker beeld te krijgen van de ervaren werkkenmerken en de relaties tussen werkkenmerken en welzijn. Deze studie komt ook tegemoet aan de vraag om niet alleen oudere werknemers te bestuderen met een relatief sterke arbeidsmarktpositie (De Lange et al., 2006). Bovendien gaat onze aandacht nu niet uit naar de motivatie om te leren, maar naar de positieve (arbeidsvreugde) en negatieve (spanning, met als indicatoren herstelbehoefte, slaapdeprivatie en vermoeidheid) aspecten van welzijn. Als theoretisch kader volgen we hierbij het Job Demands-Resources (JDR) model (Bakker \& Demerouti, 2007; Demerouti, Bakker, Nachreiner \& Schaufeli, 2001). Dit model stelt ons in de gelegenheid om een verscheidenheid aan werkkenmerken te bestuderen en om hun relaties met zowel spanning als arbeidsvreugde empirisch te onderzoeken.

\section{Het Job Demands-Resources model}

Het JDR-model suggereert dat in iedere werkomgeving uiteenlopende werkkenmerken een invloed kunnen hebben op het (on)welbevinden en het functioneren van werknemers. Deze werkkenmerken kunnen ingedeeld worden als werkeisen (job demands) of energiebronnen (job resources). Werkeisen omvatten alle fysieke, psychologische, sociale of organisatorische aspecten van het werk die het volhouden van een bepaalde fysieke en/of mentale inspanning vereisen. Daarom brengen zij bepaalde fysiologische en/of psychologische kosten met zich mee (Demerouti et al., 2001). Energiebronnen omvatten alle fysieke, psychologische, sociale of organisatorische aspecten van het werk die: (1) werkeisen en de daar- 
De relatie tussen werkeisen, energiebronnen, spanning en werkplezier: een kwestie van leeftijd?

mee verbonden fysiologische en/of psychologische kosten reduceren, (2) bijdragen aan het realiseren van werkgerelateerde doelen, en (3) persoonlijke groei en ontwikkeling stimuleren (Demerouti et al., 2001). In dit artikel bestuderen we het voorkomen en de invloed van werktempo/hoeveelheid, rolconflict, en veranderingen in het werk als werkeisen en relaties met collega's, relatie met leidinggevende en autonomie als werkhulpbronnen. Deze werkkenmerken komen immers frequent voor in hedendaagse organisaties (Parker, Wall \& Cordery, 2001) en komen mogelijk in verschillende mate voor en/of hebben verschillende effecten voor medewerkers van verschillende leeftijden.

In het algemeen wordt aangenomen dat hoge werkeisen leiden tot een voortdurende aantasting van mentale en fysieke energiereserves, wat op termijn leidt tot chronische emotionele uitputting en burn-out. Dit kan op zijn beurt resulteren in negatieve uitkomsten zoals gezondheidsklachten (Hakanen, Bakker \& Schaufeli, 2006) en ziekteverzuim (Schaufeli, Bakker \& Van Rhenen, 2009). De aanwezigheid van energiebronnen leidt daarentegen tot verhoogde motivatie en daarom ook tot bevlogenheid (Bakker, Schaufeli, Leiter \& Taris, 2008), wat op haar beurt bijvoorbeeld resulteert in meer organisatiebetrokkenheid (Hakanen, Schaufeli \& Ahola, 2008) en verhoogde productiviteit (Xanthopoulou, Bakker, Demerouti \& Schaufeli, 2009).

Het JDR-model is in de afgelopen jaren uitgebreid empirisch gevalideerd (zie bijv. Boyd, Bakker, Pignata, Winefield, Gillespie \& Stough, 2011; Lewig, Xanthopoulou, Bakker, Dollard \& Metzer, 2007; Schaufeli et al., 2009). De rol van leeftijd binnen het model bleef echter grotendeels onderbelicht. Leeftijd wordt in de regel beschouwd als een 'storende' variabele die behandeld wordt als een controlevariabele (bijv. Van den Broeck, Vansteenkiste, De Witte \& Lens, 2008) of uit de analyses wordt weggelaten (bijv. Bakker, Demerouti \& Schaufeli, 2003). Nochtans zijn er heel wat redenen om aan te nemen dat oudere en jongere werknemers verschillen in de mate waarin ze bepaalde werkkenmerken ervaren, en dat er leeftijdsverschillen bestaan met betrekking tot de impact van werkkenmerken op het welzijn van medewerkers. In de volgende sectie zetten we deze redenen uiteen.

\section{Werkeisen en energiebronnen in functie van leeftijd}

Ouder worden is meer dan alleen een toename in kalenderleeftijd. Het is een complex proces dat bestaat uit talloze veranderingen op het vlak van lichamelijk functioneren, waarneming, denken, motivatie, emoties, sociale relaties, en zingeving (Kooij, De Lange, Jansen \& Dikkers, 2008; Kooij, De Lange, Jansen, Kanfer \& Dikkers, 2011). Een aantal van deze veranderingen gaat ontegensprekelijk gepaard met verlies (Baltes \& Dickson, 2001). Zo vertraagt onze stofwisseling met het ouder worden (McArdle, Vasilaki \& Jackson, 2002), verliezen we gaandeweg spiermassa, gaan onze visuele en auditieve functies achteruit (Lindenberger \& Baltes, 1994), en wordt het denken en reageren trager en minder efficiënt (Salthouse, 1996).

Ondanks de biologische achteruitgang slagen de meeste ouderen erin om prima te blijven functioneren. Ouderen kunnen immers terugvallen op een uitgebreidere 
Bert Schreurs, Anja Van den Broeck, Guy Notelaers, Beate van der Heijden \& Hans De Witte

kennis en ervaring en een hogere mate van emotionele volwassenheid (Ackerman \& Rolfhus, 1999). Volgens de Selectie-Optimalisatie-Compensatie (SOC) theorie (Baltes \& Dickson, 2001) zijn ze ook selectiever in wat ze willen bereiken, zetten ze de beschikbare middelen optimaler in en compenseren ze verlies door hun doelen bij te stellen of door ze op een andere manier na te streven. Het toepassen van deze drie strategieën (d.w.z. selecteren, optimaliseren en compenseren) blijkt daadwerkelijk bij te dragen tot succesvol ouder worden (bijv. Freund \& Baltes, 1998). Daarom zijn ze mogelijk ook van invloed op de ervaring van werkeisen en energiebronnen en modereren ze mogelijk ook de impact van deze werkkenmerken op (on)welbevinden en het functioneren van medewerkers.

Mogelijk komen werknemers, naarmate ze ouder worden, bijvoorbeeld terecht in kwalitatief betere functies (d.w.z. functies met minder werkeisen en met meer energiebronnen) omdat ze selectiever zijn in het uitkiezen van en het vormgeven aan hun functies. De 'job change hypothesis' (Wright \& Hamilton, 1978) voorspelt immers dat werknemers met het ouder worden meer tijd hebben om uit te zoeken welke functie met welke werkkenmerken bij hen past en daardoor meer kans maken om deze functie te verkrijgen. Volgens de Socio-emotional Selectivity Theory (SST, Carstensen, 2006) hechten ouderen bijvoorbeeld meer belang aan kwalitatief goede sociaal-emotionele relaties dan jongeren. Naarmate we ouder worden, wordt de tijd die ons rest tot aan onze dood steeds schaarser, en dus ook kostbaarder (Lang \& Carstensen, 2002). Ouderen hebben bijgevolg een voorkeur voor het uitdiepen van een beperkt aantal waardevolle relaties boven het ontwikkelen van een uitgebreid sociaal netwerk. Daarom investeren werknemers vanaf een bepaalde leeftijd mogelijk minder in hun professionele netwerk en meer in hun familiaire relaties, waardoor ze ook minder steun van hun naaste collega's en hun leidinggevende ontvangen (De Lange et al., 2010; Kooij et al., 2011). Het is eveneens plausibel dat werknemers naarmate ze ouder worden meer autonomie verwerven in hun baan, omdat ze promoveren naar een 'senior' positie, jarenlange ervaring bezitten binnen dezelfde functie en/of soepeler gesuperviseerd worden (Warr, 2007). Deze autonomie stelt oudere werknemers vervolgens in staat om zelf hun baan selectiever vorm te geven. In lijn hiermee tonen studies aan dat een hogere leeftijd samengaat met meer autonomie, meer controle over tijdsbesteding en werkmethodes en meer mogelijkheden om vaardigheden en expertise te benutten (bijv. De Lange, De Witte \& Notelaers, 2008). Samengevat leidt dit tot de volgende hypothese ten aanzien van de energiebronnen:

Hypothese 1: Oudere werknemers rapporteren de minste sociale steun van collega's en leidinggevende, eerst gevolgd door werknemers uit de middengroep en dan door jongere werknemers. Oudere werknemers scoren het hoogst op autonomie in het werk, eerst gevolgd door werknemers uit de middengroep en dan door jongere werknemers.

Een gelijkaardige redenering kan opgebouwd worden voor de werkeisen: in vergelijking met jongere werknemers worden oudere werknemers na verloop van tijd selectiever op het vlak van werkeisen en komen ze terecht in minder veeleisende functies. 
De relatie tussen werkeisen, energiebronnen, spanning en werkplezier: een kwestie van leeftijd?

Oudere werknemers zouden bijvoorbeeld lager scoren op werktempo/hoeveelheid als gevolg van bijvoorbeeld 'job change': oudere werknemers weten immers beter waar de grenzen van hun kunnen liggen en kunnen terugvallen op een ruime expertise om de werkdruk aan te kunnen (Berk, 2004). Omdat oudere werknemers meestal meer ervaring hebben in hun baan en in hun arbeidsorganisatie, zouden ze minder rolconflicten kunnen ervaren dan hun jongere collega's. Rolconflicten manifesteren zich immers hoofdzakelijk in het begin van de loopbaan of bij de start van een nieuwe functie (Van Maanen, 1975). Oudere werknemers worden bovendien gestereotypeerd als minder flexibel en intoleranter ten aanzien van veranderingen in het werk dan jongere werknemers (Weiss \& Maurer, 2004). Bijgevolg worden ouderen vaak niet betrokken bij activiteiten die verandering impliceren (bijv. training/opleiding en beleid), wat een negatieve relatie tussen leeftijd en hinder van veranderingen in het werk impliceert. Samengevat leidt dit tot de volgende hypothese ten aanzien van de werkeisen:

Hypothese 2: Oudere werknemers percipiëren het minst hoge werktempo, de minste rolconflicten en de minste hinder van veranderingen in het werk, eerst gevolgd door werknemers uit de middengroep en dan door jongere werknemers.

De SOC-theorie kan ook verklaren waarom we verwachten dat de impact van werkeisen en -hulpbronnen anders zal zijn voor werknemers van verschillende leeftijden. Meer bepaald gaan we ervan uit dat ouderen door het proces van optimalisatie beter gebruik zullen maken van hun energiebronnen om hun doelen te bereiken en dus dat met het ouder worden de aanwezige energiebronnen een sterkere positieve invloed hebben op welzijn en op arbeidsvreugde. De Person-Organization fit (P-O fit; Kristof-Brown, Zimmerman \& Johnson, 2005) gedachte veronderstelt immers dat een overeenkomst tussen de behoeften van werknemers en datgene wat de werkomgeving te bieden heeft, doorgaans leidt tot positieve uitkomsten, zoals arbeidsvreugde en tevredenheid met het werk. Terwijl jongere werknemers meer belang hechten aan instrumentele werkkenmerken, zoals salaris en promotiemogelijkheden, zijn ouderen meer gericht op autonomie en kwalitatief goede sociale relaties (Warr, 2008). De aanwezigheid van deze energiebronnen vervult dus vooral de behoeften van ouderen, waardoor zij een betere fit en meer welzijn zullen ervaren.

Dit hoeft niet in tegenspraak te zijn met de idee dat ouderen minder investeren in het onderhouden en uitbreiden van hun sociaal netwerk en daardoor gemiddeld minder werkrelaties hebben dan jongeren. Hier stellen we immers dat ouderen meer profijt halen uit de sociale relaties die ze wel konden ontwikkelen, dat het effect van sociale relaties verschilt in functie van leeftijd.

Hypothese 3: De positieve relatie tussen energiebronnen (d.w.z. relaties met collega's, relatie met de leidinggevende en autonomie in het werk) en arbeidsvreugde is het sterkst voor oudere werknemers, eerst gevolgd door werknemers uit de middengroep en dan door jongere werknemers.

Tot slot verwachten we dat werkeisen meer bepalend zijn voor het welbevinden van oudere dan van jongere werknemers. Werkeisen vragen immers om volgehou- 
Bert Schreurs, Anja Van den Broeck, Guy Notelaers, Beate van der Heijden \& Hans De Witte

den fysieke en/of mentale inspanningen. Precies op die terreinen treedt er met het ouder worden verlies op. Ouderen zullen dit verlies doorgaans wel kunnen compenseren, maar dit vraagt bijkomende energie die waarschijnlijk eerder tot een status-quo leidt dan tot een surplus. Volgens de Conservation of Resources theorie (Hobfoll, 1989) leidt dit tot meer stress en minder welbevinden.

Door leeftijdsgerelateerde fysieke en cognitieve veranderingen zouden oudere werknemers meer kunnen lijden wanneer ze, ondanks de selectiemechanismen zoals hierboven beschreven werden, geconfronteerd worden met grote werkvolumes en een strak werktempo (Jex, Wang \& Zarubin, 2007). Ook bestaan er aanwijzingen dat ouderen meer hinder ondervinden van rolconflicten (Mayes, Barton \& Ganster, 1991). Ouderen zouden er immers minder goed in slagen een evenwicht te handhaven tussen hun verschillende werkrollen, omdat dit meer fysieke en mentale energie vraagt dan ze daadwerkelijk bezitten. Tot slot wordt gesuggereerd dat ouderen meer lijden wanneer ze betrokken worden bij werkinhoudelijke veranderingen (Yeatts, Folts \& Knapp, 2000). Oudere werknemers zijn vaker geroutineerd in een bepaald expertisedomein waardoor ze het moeilijker zouden hebben om over te schakelen op andere werkmethodes of om hetzelfde niveau te behalen binnen andere structuren (Thijssen \& Van der Heijden, 2003). Bovendien zou onder oudere werknemers de vrees bestaan dat veranderingen in de werkcontext zullen leiden tot verlies van verworven status en privileges (Mullan \& Gorman, 1972).

Opnieuw is het belangrijk een onderscheid te maken tussen het gemiddelde niveau van werkeisen en het effect van deze werkeisen op werkuitkomsten. Terwijl hypothese 2 voorstelt dat ouderen terechtkomen in banen met gemiddeld lagere werkeisen, rolconflicten en hinder van veranderingen in het werk, stellen we hier dat ouderen meer hinder ondervinden van de aanwezige werkeisen dan jongeren en dat dit zich vertaalt in een sterkere relatie tussen de werkeisen die desondanks aanwezig zijn en werkuitkomsten. Dit laatste leidt tot de volgende hypothese:

Hypothese 4: De positieve relatie tussen werkeisen (d.w.z. werktempo/hoeveelheid, rolconflicten en hinder van veranderingen in het werk) en spanning is het sterkst voor oudere werknemers, eerst gevolgd door werknemers uit de middengroep en dan door jongere werknemers.

De leeftijdsgrens om oudere werknemers van jongere werknemers te onderscheiden ligt niet vast. Vaak wordt de grens voor oudere werknemers op 45 jaar gelegd (bijv. De Lange et al., 2010), maar ook onder die leeftijd blijken werknemers het niet altijd gemakkelijk te hebben in hun arbeidzame leven (Berk, 2004). In dit onderzoek willen we een levensloopperspectief hanteren en drie leeftijdsgroepen bestuderen: (1) werknemers tussen de 18 en 35 jaar worden beschouwd als jongere werknemers; (2) de middengroep wordt gevormd door werknemers tussen de 36 en 45 jaar; (3) werknemers ouder dan 45 worden tot slot gecategoriseerd als oudere werknemers (zie ook Collins, 2003; Finkelstein \& Farrell, 2007). 


\section{Methode}

\subsection{Procedure}

De data voor deze studie werden tussen 1999 en 2007 verzameld door de Directie van het Onderzoek voor de Verbetering van de Arbeidsomstandigheden (DiOVA) in 142 verschillende organisaties, met de medewerking van verschillende externe preventiediensten. Meestal werd het voltallige personeel van een organisatie of afdeling bevraagd. Soms werd de afname klassikaal georganiseerd door de externe preventiediensten. De anonimiteit van de respondent werd steeds gegarandeerd. De ingevulde vragenlijsten werden verzameld in een afgesloten verzameldoos ofwel per post in een voorgefrankeerde enveloppe naar het DiOVA verzonden. Het DiOVA bracht alle data samen in een heterogene databank met voldoende gegevens om zinvolle uitspraken te doen voor een populatie van bijna 200 beroepen en in een 20 -tal subsectoren.

\subsection{Steekproef}

De totale sample bestond uit 15.464 respondenten (tabel 1). Er participeerden meer mannen dan vrouwen. Oudere werknemers waren relatief vaker lager geschoold dan de jongeren. Ouderen oefenden ook vaker een leidinggevende functie uit in vergelijking met de andere leeftijdscategorieën en werkten meer in dagdienst. Van alle werknemers werkten jongeren het vaakst in ploegendienst.

\subsection{Metingen}

Alle variabelen werden gemeten aan de hand van de Vragenlijst Beleving en Beoordeling van de Arbeid (VBBA; Van Veldhoven, Meijman \& Broersen, 2002). Tenzij anders vermeld werden alle items gescoord op een vierpuntsschaal $(0=$ 'nooit' tot 3 = 'altijd'). De schaalscores van alle variabelen kwamen tot stand door het schaalgemiddelde te berekenen over de desbetreffende items, gevolgd door een omzetting naar een schaal van 0 tot 10 .

\section{- Energiebronnen}

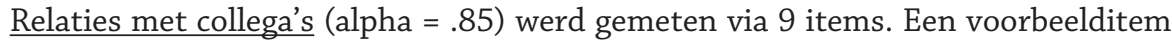
is: 'Kunt u, als dat nodig is, uw collega's om hulp vragen?' Relaties met direct leidinggevende (alpha $=.90$ ) werd eveneens gemeten aan de hand van 9 items zoals 'Is uw directe leidinggevende vriendelijk tegen u?' Autonomie (alpha $=.91$ ) werd gemeten via 11 items. Een voorbeelditem is: 'Kunt u zelf bepalen hoe u uw werk uitvoert?'

\section{- Werkeisen}

Werktempo/hoeveelheid (alpha $=.88$ ) werd gemeten via 11 items zoals: 'Moet u extra hard werken om iets af te krijgen?' Rolconflicten (alpha $=.76$ ) werd gemeten via 6 items zoals 'Krijgt u tegenstrijdige opdrachten?' Veranderingen in het werk en de mogelijke hinder die hiermee gepaard gaat (alpha $=.66$ ) werd gemeten via vijf items. Een voorbeelditem is: 'Treden er belangrijke veranderingen op in uw werk?' 
Tabel 1 Demografische kenmerken en informatie over type werk van werknemers uit de jongeren-, midden- en ouderengroep (gemiddeldes; standaarddeviaties tussen haakjes)

\begin{tabular}{|c|c|c|c|}
\hline & $\begin{array}{l}\text { Jongeren } \\
\leq 35 \text { jaar } \\
N=3.850\end{array}$ & $\begin{array}{l}\text { Midden } \\
36-45 \text { jaar } \\
N=7.273\end{array}$ & $\begin{array}{l}\text { Ouderen } \\
>45 \text { jaar } \\
N=4.34 I\end{array}$ \\
\hline Leeftijd* & $26,27(2,8 I)$ & $37,24(3,93)$ & $50,61(4,18)$ \\
\hline Werkervaring binnen huidige organisatie* & $3,52(3,55)$ & $10,24(6,5 \mid)$ & $20,54(9,97)$ \\
\hline Werkervaring binnen huidige functie* & $3,16(3,75)$ & $7,84(6,53)$ & $|4,3|(10,16)$ \\
\hline \% Mannen* & $50,2 \%$ & $53,4 \%$ & $63,5 \%$ \\
\hline \multicolumn{4}{|l|}{ \% Opleidingsniveau* } \\
\hline I. Max. diploma lager onderwijs & $0,7 \%$ & $2,2 \%$ & $8,2 \%$ \\
\hline 2. Lager secundair onderwijs & $6,9 \%$ & $13,0 \%$ & $21,5 \%$ \\
\hline 3. Hoger secundair onderwijs & $38,4 \%$ & $36,2 \%$ & $33,8 \%$ \\
\hline 4. Hoger onderwijs korte type & $32,7 \%$ & $26,9 \%$ & $19,3 \%$ \\
\hline 5. Hoger onderwijs lange type/ universiteit & $21,4 \%$ & $21,6 \%$ & $17,2 \%$ \\
\hline \% Leidinggevende functie* & $10,3 \%$ & $22,3 \%$ & $28,1 \%$ \\
\hline \multicolumn{4}{|l|}{ \% Werkregime* } \\
\hline I. Dagdienst & $75,0 \%$ & $81,5 \%$ & $84,5 \%$ \\
\hline 2. Ploegendienst & $18,8 \%$ & $13,6 \%$ & $10,5 \%$ \\
\hline 3. Onregelmatige dienst & $4,3 \%$ & $3,3 \%$ & $4,3 \%$ \\
\hline 4. Nachtdienst & $\mathrm{I}, 8 \%$ & $1,3 \%$ & $1,0 \%$ \\
\hline 5. Weekenddienst & $0,1 \%$ & $0,3 \%$ & $0,1 \%$ \\
\hline \multicolumn{4}{|l|}{ \% Sector* } \\
\hline I. Secundaire sector & $48,2 \%$ & $45,9 \%$ & $35,7 \%$ \\
\hline 2. Tertiaire sector & $26,1 \%$ & $19,1 \%$ & $16,8 \%$ \\
\hline 3. Quartaire sector & $25,8 \%$ & $35,1 \%$ & $47,5 \%$ \\
\hline
\end{tabular}

NB. * = significante verschillen tussen leeftijdscategorieën:

Leeftijd $F(2,15463)=43162.06(p<.001)$

Werkervaring binnen huidige organisatie $F(2,15463)=5756.74(p<.001)$

Werkervaring binnen huidige functie $F(2,15463)=2215.72(p<.00 \mathrm{I})$

Geslacht $\chi^{2}(2)=165.25(p<.00 I)$

Opleidingsniveau $\chi^{2}(8)=893.50(p<.001)$

Leidinggevend $\chi^{2}(2)=337.10(p<.001)$

Werkregime $\chi^{2}(8)=138.26(p<.001)$

Sector $\chi^{2}(4)=456.42(p<.00 I)$

\section{- $\quad$ Spanning}

Spanning werd geoperationaliseerd aan de hand van de volgende drie VBBAschalen: herstelbehoefte, slaapdeprivatie (slaapkwaliteit) en vermoeidheid. Herstelbehoefte $(K R-20=.87)$ werd gemeten aan de hand van 11 dichotome $(0=$ 'neen'; 1 = 'ja') items zoals 'Het kost mij over het algemeen meer dan een uur voordat ik helemaal hersteld ben na mijn werk.' Slaapkwaliteit $($ KR-20 $=.88)$ werd gemeten met behulp van 14 dichotome ( 0 = 'neen'; $1=$ 'ja') items zoals 'Ik 
De relatie tussen werkeisen, energiebronnen, spanning en werkplezier: een kwestie van leeftijd?

doe 's nachts vaak geen oog dicht.' Vermoeidheid tijdens het werk (alpha $=.97$ ), ten slotte, werd gemeten aan de hand van 16 bipolaire items met vijf antwoordcategorieën. Een item dat deze schaal illustreert is: 'Geen moeite met aandacht' versus 'Aandacht zakt telkens weg'.

\section{- Arbeidsvreugde}

Arbeidsvreugde $(\mathrm{KR}-20=.80)$ werd gemeten aan de hand van 6 dichotome $(0=$ 'neen'; 1 = 'ja') items uit de VBBA-schaal 'plezier in het werk'. Een voorbeelditem is: 'Meestal vind ik het wel prettig om aan de werkdag te beginnen.'

\subsection{Analyses}

Binnen SPSS 17.0 werden variantieanalyses (ANOVA's) en geplande vergelijkingen uitgevoerd om mogelijke verschillen tussen de gemiddelden van de drie onderscheiden leeftijdsgroepen te achterhalen. Covariantie-structuuranalyses werden uitgevoerd door middel van LISREL 8.54 om de relaties tussen werkkenmerken (i.e., werkeisen en energiebronnen) en arbeidsvreugde en spanning te onderzoeken en om na te gaan of deze relaties verschillen in functie van leeftijd. Hierbij werden drie stappen gevolgd. In een eerste stap werd in de volledige steekproef (zonder onderscheid tussen leeftijdscategorieën) onderzocht of het vooropgestelde onderzoeksmodel bij de data past. In dit model werden positieve relaties verondersteld tussen werkeisen en spanning en tussen energiebronnen en arbeidsvreugde. De correlaties tussen werkeisen en energiebronnen en tussen arbeidsvreugde en spanning werden vrij geschat. De schalen werktempo/hoeveelheid, rolconflicten en veranderingen in het werk waren indicatoren van het latente construct werkeisen; de schalen relaties met collega's, relatie met de leidinggevende en autonomie waren indicatoren van het latente construct energiebronnen. Zes items werden gebruikt als indicator van het latente construct arbeidsvreugde. De schalen herstelbehoefte, slaapkwaliteit en vermoeidheid fungeerden als indicatoren van het latente construct spanning.

In een tweede stap werd onderzocht of andere modellen beter bij de data pasten. In een derde stap werden multi-groep structurele vergelijkingsanalyses uitgevoerd om na te gaan of de structurele relaties in het model verschillen in functie van de onderscheiden leeftijdsgroepen. Om te beoordelen hoe goed de modellen aansloten bij de data gebruikten we de volgende absolute fitmaten: (1) de Chi-square Goodness-of-Fit test ( $\chi^{2}$-test), (2) de Standardized Root Mean Square Residual (SRMR) en (3) de Root Mean Square Error of Approximation (RMSEA). Tevens rapporteren we de volgende incrementele fitmaten: (4) de Non-Normed Fit Index (NNFI) en (5) de Comparative Fit Index (CFI). RMSEA-waarden van .05 en SRMRwaarden van .08 of kleiner duiden op een goede fit met de data (Hu \& Bentler, 1999). Voor de incrementele fitmaten geldt dat waarden van .95 of groter in het algemeen duiden op een goede beschrijving van de data (Hoijtink \& De Jonge, 2007). De $\chi^{2}$-test is gebruikt om de zogenaamde 'geneste' modellen te vergelijken. Deze analyses kunnen opgevraagd worden bij eerste auteur. 
Bert Schreurs, Anja Van den Broeck, Guy Notelaers, Beate van der Heijden \& Hans De Witte

\section{Resultaten}

Tabel 2 presenteert de correlaties tussen de onderzoeksvariabelen voor de drie leeftijdscategorieën. De mate van ervaren werkeisen bleek positief gecorreleerd te zijn met herstelbehoefte en vermoeidheid, en negatief met slaapkwaliteit en arbeidsvreugde. De mate van ervaren energiebronnen bleek positief gecorreleerd te zijn met slaapkwaliteit en arbeidsvreugde, en negatief met herstelbehoefte en vermoeidheid.

\subsection{Vergelijking van de gemiddelde scores voor de verschillende leeftijdscategorieën}

Univariate ANOVA's met leeftijd als factor laten significante verschillen zien voor alle onderzoeksvariabelen (tabel 3). Voor wat betreft energiebronnen, bleek dat oudere werknemers de hoogste mate van autonomie ervaren, eerst gevolgd door werknemers van de middengroep en dan door jongere werknemers. Zoals verwacht waren de jongere werknemers het meest positief over hun relaties met collega's en hun leidinggevende, gevolgd door oudere werknemers en de middengroep, die onderling echter niet significant van elkaar verschilden. Hypothese 1 wordt hiermee grotendeels bevestigd.

Voor wat betreft werkeisen gaven oudere werknemers te kennen meer werktempo/hoeveelheid te ervaren dan jongere werknemers, en meer geconfronteerd te worden met hinderlijke veranderingen in hun werk dan werknemers uit de andere leeftijdscategorieën. Werknemers uit de middengroep bleken het vaakst te maken te hebben met rolconflicten. We vinden met deze uitkomst dus geen ondersteuning voor hypothese 2 die stelt dat oudere werknemers het laagst zullen scoren op werkeisen, gevolgd door werknemers uit de middengroep en jongere werknemers.

\subsection{Test van het Job Demands-Resources model}

Vier alternatieve modellen werden getoetst. Het basismodel (M1) veronderstelt positieve relaties tussen werkeisen en spanning en tussen energiebronnen en arbeidsvreugde. In het tweede model (M2) werd, in navolging van eerder onderzoek (bijv. Bakker et al., 2004; Hakanen et al., 2006; Schaufeli \& Bakker, 2004), een kruisverband toegevoegd van energiebronnen naar spanning (M2). Dit model toetst de veronderstelling dat de aanwezigheid van energiebronnen niet alleen een positieve relatie heeft met arbeidsvreugde, maar dat de afwezigheid van energiebronnen tevens leidt tot de ontwikkeling van spanning, zoals ook wordt aangegeven in de literatuur over burn-out (Halbesleben \& Buckley, 2004). Het derde model bevat een kruisverband tussen werkeisen en arbeidsvreugde (M3) (Schreurs, Van Emmerik, De Cuyper, Notelaers \& De Witte, 2011). Dit model toetst de mogelijkheid dat de aanwezigheid van werkeisen niet alleen energie vraagt, maar dat de afwezigheid van werkeisen ook motivatiebevorderend werkt. Het vierde model, tot slot, bevat beide vooropgestelde paden en beide kruisverbanden (M4).

Uit tabel 4 blijkt dat het basismodel (M1) goed bij de data past en beter past dan het model met beide kruisverbanden (M4). M2 en M3 passen ook goed bij de data, maar zijn minder spaarzaam dan M1, dat daarom onze voorkeur heeft. De 
De relatie tussen werkeisen, energiebronnen, spanning en werkplezier: een kwestie van leeftijd?

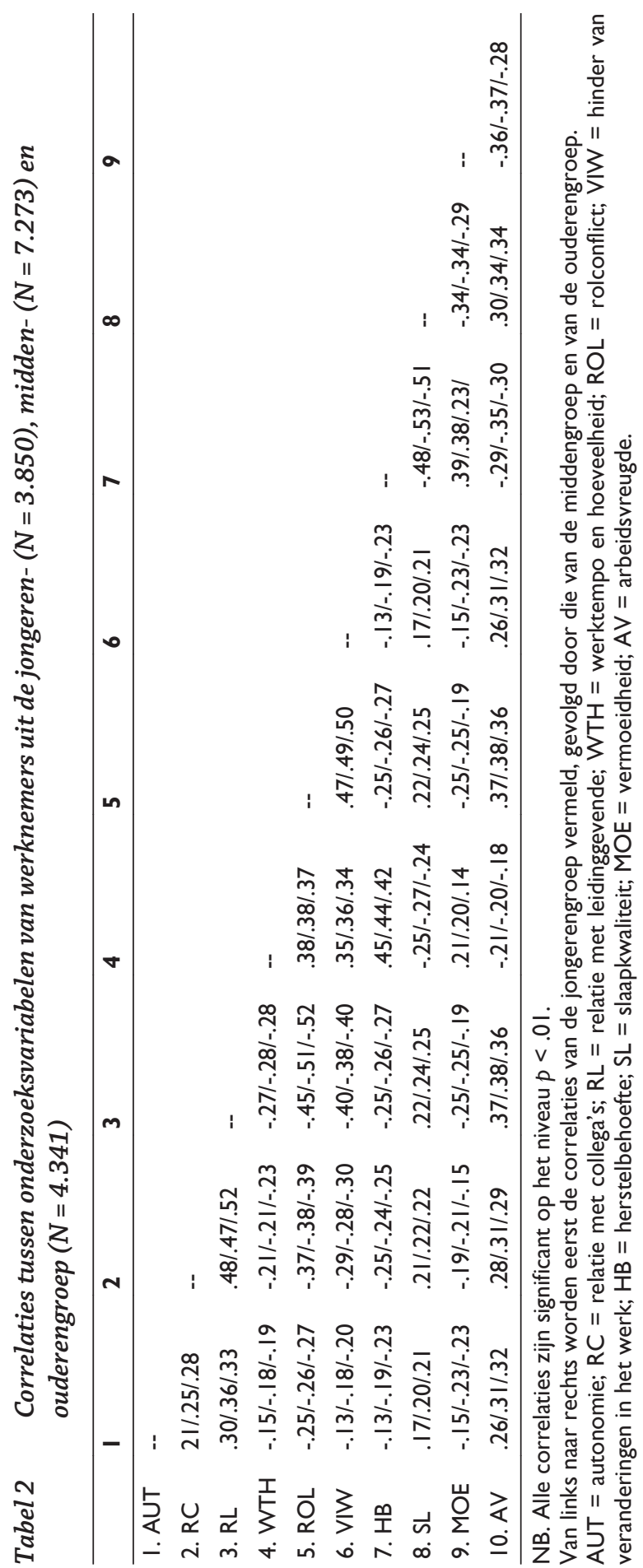


Tabel 3 Gemiddeldes, standaardafwijkingen en resultaten van ANOVA's

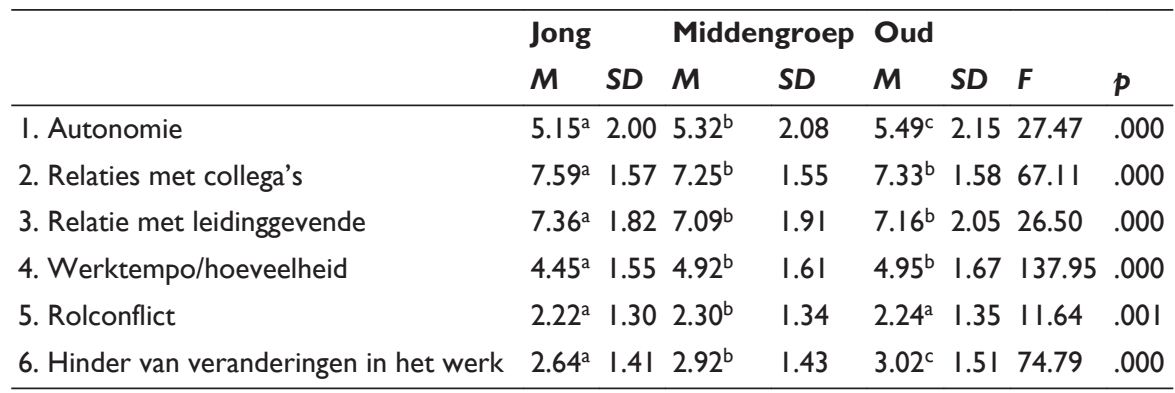

NB. $N=15.464$ voor alle analyses.

De bovenindex duidt aan welke leeftijdscategorieën significant van elkaar verschillen. Bij eenzelfde index verschillen de categorieën niet significant van elkaar.

Tabel 4 Fit indices en chi $^{2}$ verschil-toetsen van diverse geneste modellen in een covariantie-structuuranalyse voor de totale groep $(N=15.464)$

\begin{tabular}{|c|c|c|c|c|c|c|c|c|c|}
\hline Model & $\chi^{2}$ & $d f$ & RMSEA & SRMR & CFI & NNFI & $\begin{array}{l}\text { Model- } \\
\text { vergelij- } \\
\text { kingen }\end{array}$ & $\Delta \chi^{2}$ & $\Delta d f$ \\
\hline $\begin{array}{l}\text { I Model zonder cross- } \\
\text { links (MI, zie fig. I) }\end{array}$ & $4195.05^{* *}$ & 86 & .056 & .042 & .97 & .96 & & & \\
\hline $\begin{array}{l}2 \text { Model met cross-link } \\
\text { van energiebronnen } \\
\text { naar onwelbevinden } \\
\text { (M2) }\end{array}$ & $4197.19 * *$ & 85 & .056 & .042 & .97 & .96 & M2 - MI & 2.14 & I \\
\hline $\begin{array}{l}3 \text { Model met cross-link } \\
\text { van werkeisen naar } \\
\text { arbeidsvreugde (M3) }\end{array}$ & $4198.15^{* *}$ & 85 & .056 & .042 & .97 & .96 & M3 - MI & 3.10 & I \\
\hline $\begin{array}{l}4 \text { Model met beide } \\
\text { cross-links (M4) }\end{array}$ & $4198.89 * *$ & 84 & .057 & .042 & .97 & .96 & M4 - MI & $3.84 *$ & 2 \\
\hline
\end{tabular}

relaties in M1 tonen aan dat werkeisen positief samenhangen met spanning $(\gamma=.64)$ en dat energiebronnen positief gerelateerd zijn aan arbeidsvreugde $(\gamma=.56)$.

\subsection{Multi-groep structurele vergelijkingsanalyses}

In een volgende analyse onderzochten we of de relaties in M1 invariant zijn voor jongeren, werknemers uit de middengroep en oudere werknemers door bepaalde parameters in het model systematisch vrij te laten. In het eerste model (M5) werden alle factorladingen, padcoëfficiënten en structurele varianties en covarianties gelijkgesteld voor de drie leeftijdscategorieën. In het tweede model (M6) werden de structurele paden voor alle leeftijdscategorieën vrij geschat. In het derde model (M7) werden de structurele paden, de structurele varianties en de covarianties (d.w.z. tussen energiebronnen en werkeisen en tussen arbeidsvreugde en spanning) vrij geschat voor iedere leeftijdscategorie. Tot slot werd een model (M8) 
Tabel 5 Resultaten van de multi-groep structurele vergelijkingsanalyse voor de jongeren- $(N=3.850)$, midden- $(N=7.273)$ en ouderengroep $(N=$ 4.341)

\begin{tabular}{|c|c|c|c|c|c|c|c|c|c|}
\hline Model & $\chi^{2}$ & $d f$ & RMSEA & SRMR & CFI & NNFI & $\begin{array}{l}\text { Model- ver- } \\
\text { gelijkingen }\end{array}$ & $\Delta \chi^{2}$ & $\Delta d f$ \\
\hline $\begin{array}{l}\text { I Alle paden gelijk- } \\
\text { gesteld (M5) }\end{array}$ & 5503.86 & 326 & .056 & .058 & .96 & .96 & & & \\
\hline $\begin{array}{l}2 \text { Structurele paden } \\
\text { vrij geschat (M6) }\end{array}$ & 5475.40 & 322 & .056 & .059 & .96 & .96 & M5 - M6 & $28.46^{* *}$ & 4 \\
\hline $\begin{array}{l}3 \text { Structurele paden, } \\
\text { structurele co- } \\
\text { varianties en struc- } \\
\text { turele varianties } \\
\text { vrij geschat (M7) }\end{array}$ & 5364.76 & 310 & .056 & .049 & .96 & .96 & M5 - M7 & $139.10^{* *}$ & 16 \\
\hline $\begin{array}{l}4 \text { Alle parameters } \\
\text { vrij geschat (M8) }\end{array}$ & 5285.35 & 288 & .058 & .050 & .96 & .96 & M5 - M8 & $218.5 \mathrm{I}^{* *}$ & 38 \\
\hline 5 Finale model (M9) & 5341.78 & 313 & .056 & .053 & .96 & .96 & M5 - M9 & $162.08 * *$ & $=13$ \\
\hline
\end{tabular}

NB. ${ }^{* *}$ significant $p<.01$.

getoetst waarin alle parameters van zowel meet- als structureel model vrij werden geschat voor elke leeftijdscategorie (tabel 5). Alle meer restrictieve modellen wijken significant af van het basismodel (M1). Het JDR-model is dus variant voor de verschillende leeftijdscategorieën.

Ten slotte bekijken we welke parameters verantwoordelijk zijn voor de verschillen tussen de leeftijdscategorieën door alle parameters in de drie groepen één voor één vrij te laten, startend vanuit het volledig gelijkgestelde model (M5). Wanneer de fit van het model met de vrijgelaten parameter niet significant verbeterde bleef de specifieke parameter gelijkgesteld. Het finale model (M9) dat via deze procedure tot stand kwam, sluit goed aan bij de data, $\chi^{2}(313)=5341.78, p<.001$; $\mathrm{RMSEA}=.056 ; \mathrm{SRMR}=.053 ; \mathrm{CFI}=.96$; NNFI $=.96$. Figuur 1 presenteert de gestandaardiseerde coëfficiënten voor dit finale model. In geval van invariantie worden de coëfficiënten van iedere leeftijdscategorie getoond.

Jongere werknemers, werknemers uit de middengroep en oudere werknemers verschillen in termen van: (1) de factorladingen van de variabelen relaties met collega's, relatie met de directe leidinggevende, slaapkwaliteit en vier indicatoren van arbeidsvreugde; (2) de padcoëfficiënten van werkeisen naar spanning en van energiebronnen naar arbeidsvreugde; en (3) de covariantie tussen spanning en arbeidsvreugde.

Volgens hypothese 3 is de relatie tussen de verschillende energiebronnen en arbeidsvreugde sterker voor oudere werknemers dan voor respectievelijk de middengroep en jongere werknemers. De resultaten wijzen echter in een andere richting: de relatie was het sterkst voor de jongere werknemers en voor de werknemers uit de middengroep (beide $\gamma^{\prime} s=.58$ ), en het minst uitgesproken voor de oudere werknemers (.53). Ouderen lijken dus het minst te profiteren van energie- 
Figuur 1 Gestandaardiseerde coëfficiënten van het finale model (M9). Links: coëfficiënten van de jongerengroep. Midden: coëfficiënten van de middengroep. Rechts: coëfficiënten van de ouderengroep

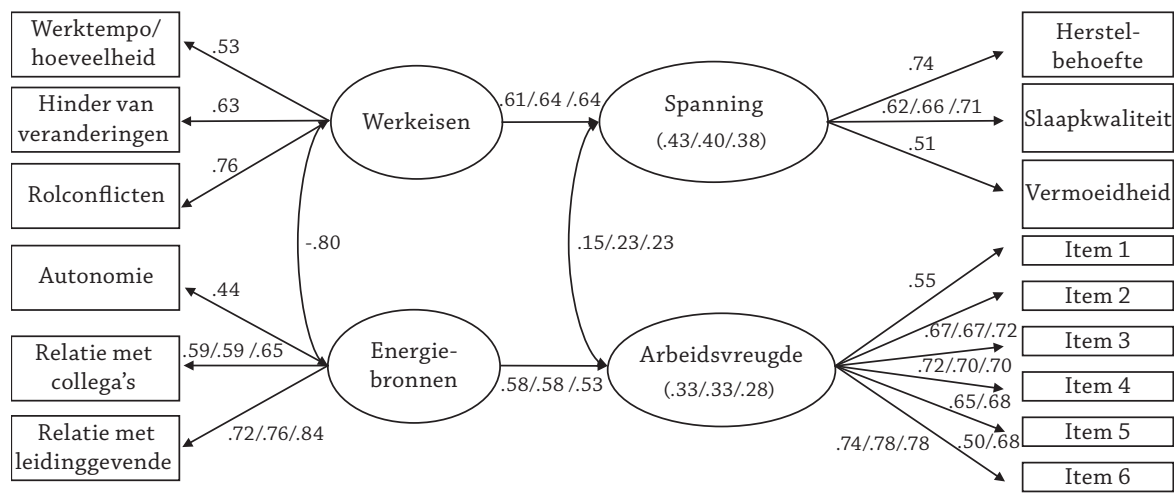

bronnen in termen van arbeidsvreugde. Hypothese 3 kan hiermee niet bevestigd worden.

Hypothese 4 stelt dat de relatie tussen werkeisen en spanning sterker is voor oudere werknemers dan voor respectievelijk de werknemers uit de middengroep en jongere werknemers. Deze hypothese wordt deels bevestigd: de relatie was het sterkst voor werknemers uit de middengroep en voor oudere werknemers (beide $\left.\gamma^{\prime} s=.64\right)$ en minder uitgesproken voor de jongere werknemers (.61). Medewerkers uit de twee oudste leeftijdsgroepen lijken dus meer last te hebben van werkeisen in termen van spanning.

\section{Discussie}

\subsection{Reflectie op de uitkomsten}

Gebruikmakende van het Job Demands-Resources (JDR) model werd naar een antwoord gezocht op twee centrale onderzoeksvragen: (1) verschillen werknemers uit verschillende leeftijdsgroepen gemiddeld genomen in het ervaren van energiebronnen (d.w.z. relaties met collega's, relatie met de direct leidinggevende en autonomie in het werk) en werkeisen (d.w.z. werktempo/hoeveelheid, rolconflict, veranderingen in het werk), en (2) zijn de relaties van deze gepercipieerde werkkenmerken met spanning en arbeidsvreugde verschillend in functie van leeftijdscategorie?

Samengevat tonen de resultaten kleine gemiddelde verschillen in ervaren werkkenmerken. Hoewel statistisch significant, zijn de verschillen tussen de leeftijdscategorieën al bij al klein. In overeenstemming met hypothese 1 blijken jongere werknemers het meest positief over de relatie die ze met hun collega's en hun leidinggevende hebben. De medewerkers uit de oudste en de middengroep zijn hierover minder positief. Dit zou erop kunnen wijzen dat jongere in vergelijking met oudere werknemers meer tijd en energie investeren in het uitbreiden en onderhouden van hun professionele netwerk (Carstensen, 2006) en hun per- 
De relatie tussen werkeisen, energiebronnen, spanning en werkplezier: een kwestie van leeftijd?

soonlijk netwerk ervaren als een vorm van sociale steun (Van Emmerik, Jawahar, Schreurs \& De Cuyper, 2011). Dit sluit aan bij de idee dat jongeren vooral gericht zijn op het ontwikkelen van een groot aantal instrumentele relaties ten voordele van hun verdere loopbaan, terwijl ouderen eerder gefocust zijn op het uitdiepen van een beperkter aantal sociaal-emotionele relaties, die mogelijk ook eerder buiten de werksituatie gelegen zijn, (Greller \& Stroh, 1995), vanwege een afnemend tijdsperspectief (Lang \& Carstensen, 2002).

Ouderen blijken een hogere mate van autonomie in hun werk te ervaren in vergelijking met hun jongere collega's. Deze bevinding sluit aan bij hypothese 1 en eerdere onderzoeksresultaten (bijv. De Lange et al., 2008). Het ondersteunt de idee dat naarmate werknemers ouder worden ze terechtkomen in functies waarin ze meer zelfstandig kunnen beslissen over het gebruik van hun tijd en expertise (Warr, 2007). Uit bijkomende analyses (op te vragen bij de eerste auteur) bleek bovendien dat de relatie tussen leeftijd en autonomie overeind bleef ongeacht het hiërarchische niveau en het aantal jaren ervaring van de werknemers. Samengevat, vinden we dus - in lijn met hypothese 1 - evidentie voor de opvatting dat ouderen vaker terechtkomen in functies die overeenkomen met hun veranderende behoeften in termen van energiebronnen.

Hypothese 2 wordt in ons onderzoek echter niet bevestigd. In tegenstelling tot deze hypothese vonden we dat oudere werknemers een grotere werkdruk ervaren. Deze groep, de zogenaamde 'sandwichgeneratie' (Spillman \& Pezzin, 2000), zit geprangd tussen enerzijds de zorg voor (klein)kinderen en anderzijds de opvang en begeleiding van hun (hoog)bejaarde ouders. De tijd en energie die deze zorgtaken met zich meebrengen gaan ten koste van de inspanningen die in het werk gestoken kunnen worden (Edwards \& Rothbard, 2000). De schaarsere tijd/energie kan een mogelijke verklaring zijn van de hogere ervaren werkdruk van 45 -plussers. Een alternatieve verklaring is dat oudere werknemers hogere posities bekleden die gepaard gaan met een hogere werkdruk. Bijkomende analyses toonden aan dat de relatie tussen leeftijd en werkdruk/tempo significant bleef na controle voor leidinggeven en voor het aantal jaren in de organisatie en in de functie, maar mogelijk is de hogere werkdruk van ouderen het gevolg van een grotere verantwoordelijkheid. In plaats van werk af te stoten, kunnen oudere werknemers, mede dankzij hun grote autonomie, hun werk actief vorm geven door meer werk naar zich toe te trekken. Een dergelijke redenering past ook binnen de verdere opdeling in werkeisen die recent in het JDR-model werd voorgesteld (Crawford, LePine \& Rich, 2010; Van den Broeck, De Cuyper, De Witte \& Vansteenkiste, 2010). Hierin wordt verondersteld dat werkdruk/tempo een uitdagende werkeis is, waar werknemers niet noodzakelijk afkerig tegenover staan.

Ook, en in tegenstelling tot hypothese 2 , blijkt dat ouderen meer hinder van veranderingen in het werk ervaren dan werknemers uit de andere leeftijdscategorieën. Hoewel veel ouderen door toename van hun verantwoordelijkheden gedurende hun loopbaan veelvuldig met veranderingen zijn geconfronteerd, en dus 'door de wol geverfd zijn', lijkt het erop dat dit niet per se betekent dat ze ook beter in staat zijn om adequater met deze veranderingen om te gaan dan hun jongere collega's. In lijn met Niessen, Swarowski en Leiz (2010) concluderen we dat de toegenomen ervaring die oudere werknemers hebben (de gemiddelde verblijfs- 
Bert Schreurs, Anja Van den Broeck, Guy Notelaers, Beate van der Heijden \& Hans De Witte

tijd in hun huidige functie bedroeg 14,31 jaar) een negatieve invloed heeft op hun vermogen om met veranderingen in hun werk om te gaan. Met andere woorden, de kans dat ze hinder ervaren van de veranderingen in hun werk neemt juist toe met het aantal jaren ervaring.

Werknemers uit de middengroep blijken het meest geconfronteerd te worden met rolconflicten. Het feit dat ouderen minder rolconflicten ervaren is wel in overeenstemming met hypothese 2 . Een mogelijke verklaring is dat oudere werknemers omwille van hun rijkere ervaring beter in staat zijn om tegenstrijdige rolverwachtingen te verzoenen (Matthews, Bulger \& Barnes-Farrell, 2010). Jex et al. (2007) gaan zelfs nog een stap verder en opperen de mogelijkheid dat oudere werknemers, door hun ervaring, beter in staat zijn om rolstress om te buigen tot iets positiefs: 'Based on past experience, such an [older] employee may be able to use this ambiguity to change or mold the job in a way that is more satisfying or compatible with his or her preferences' (p. 209).

Hypothese 3, dat oudere werknemers het meest profijt hebben van energiebronnen in termen van verhoogde arbeidsvreugde, werd niet bevestigd. De relatie tussen energiebronnen en arbeidsvreugde was het sterkst bij werknemers uit de jongeren- en de middengroep en het minst sterk bij oudere werknemers. Een mogelijke verklaring voor het laatste is dat met het ouder worden, werknemers meer en meer hun motivatie uit zichzelf putten in plaats van uit allerlei randvoorwaarden, een proces dat eventueel gevoed wordt door groeiende energiebronnen (Deci \& Ryan, 2000).

Hypothese 4 werd in onze studie slechts gedeeltelijk bevestigd. De relatie tussen werkeisen en spanning was het sterkst bij middelbare en oudere werknemers. Dit bevestigt mogelijk het compensatiemechanisme van de SOC- en de COR-theorie (Hobfoll, 1989), die stellen dat met het ouder worden werknemers steeds meer energie moeten investeren om werkeisen de baas te kunnen blijven. Omdat deze investering geen bijkomende voordelen oplevert, ervaren deze werknemers meer spanning dan de jongere werknemers die nog niet voor lichamelijk en cognitief verlies dienen te compenseren in de omgang met werkeisen.

Samengevat zijn er dus wel degelijk statistisch significante verschillen in de relatie tussen werkkenmerken, spanning en arbeidsvreugde tussen werknemers van verschillende leeftijdsgroepen. Anderzijds zijn deze verschillen te klein om verregaande conclusies aan te verbinden. Een veiliger besluit op basis van dit onderzoek is daarom dat ouderen niet meer lijken te profiteren van energiebronnen, noch meer lijken te lijden onder werkeisen dan hun jongere collega's.

Deze bevinding nuanceert tot op zekere hoogte de roep om een leeftijdsgericht beleid in termen van job design. Organisaties dienen volgens ons te investeren in het creëren van een gezonde en motiverende arbeidsinhoud voor alle werknemers, jong en oud. Bovendien zijn de behoeftes van werknemers niet alleen een functie van leeftijd maar ook - en misschien vooral - van de loopbaanfase waarin een werknemer zich bevindt. In die zin sluiten we ons aan bij de conclusie van Nauta, De Lange en Görtz (2010) dat organisaties er goed aan doen een 'levensloopbewust' beleid (in tegenstelling tot een 'leeftijdsbewust' beleid) te voeren dat erop gericht is in te spelen op de levensvraagstukken van werknemers in verschillende fasen van hun loopbaan. 
De relatie tussen werkeisen, energiebronnen, spanning en werkplezier: een kwestie van leeftijd?

\subsection{Beperkingen van deze studie en suggesties voor verder onderzoek}

Deze studie heeft een aantal beperkingen. Zo werden de variabelen slechts op één moment gemeten, en alleen aan de hand van zelfgerapporteerde vragenlijsten. Dit verhoogt de kans op antwoordtendenties. Bovendien kunnen de vastgestelde correlaties geflatteerd zijn tengevolge van gemeenschappelijke methodevariantie (Podsakoff, MacKenzie, Lee \& Podsakoff, 2003). Verder onderzoek aangaande de werkbeleving naar leeftijd is noodzakelijk om uitspraken over causaliteit te kunnen doen. Panelstudies kunnen meer specifieke informatie verschaffen over de stabiliteit en de variabiliteit in de modelvariabelen, en over veranderingen in de relaties over de tijd (bijv. De Lange et al., 2006). Dergelijke studies kunnen ook licht werpen op de impact van 'overleving' en selectieve uitval in de huidige steekproef. Omdat in deze studie de bevraging georganiseerd werd in het huidige personeelsbestand van de deelnemende arbeidsorganisaties, is het mogelijk dat de steekproef voor oudere werknemers hoofdzakelijk bestaat uit relatief fitte oude werknemers (cf. het 'healthy older worker effect'; De Lange et al., 2005). Dit maakt het moeilijker om differentiële effecten vast te stellen in de wijze waarop werkkenmerken het functioneren van de verschillende leeftijdsgroepen beïnvloeden. Het vraagt bovendien om voorzichtigheid bij het generaliseren van de gevonden effecten voor groepen oudere werknemers in het algemeen. Verder strekt het ook tot aanbeveling om in toekomstige studies naar de werkbeleving gebruik te maken van data die afkomstig zijn van verschillende bronnen (bijv. evaluatie door de leidinggevende en/of door naaste collega's of ondergeschikten; Hoffman \& Woehr, 2009), alsook gebruik te maken van meer objectieve data. Tot slot lijkt verder onderzoek noodzakelijk om de generaliseerbaarheid van onze bevindingen naar andere landen te bepalen (Fouad \& Arbona, 1994).

In deze studie werd leeftijd behandeld als een categorische variabele. Deze keuze werd ingegeven door zowel inhoudelijke als methodologische argumenten. Inhoudelijk laat de conceptualisatie van leeftijd als categorische variabele ruimte voor de mogelijkheid dat de effecten van leeftijd niet lineair maar gefaseerd verlopen. Deze benadering sluit conceptueel aan bij gefaseerde levensloop- en loopbaanmodellen (Levinson, 1986; Super, 1984). De gerapporteerde variantieanalyses en post-hoc regressieanalyses (op te vragen bij de eerste auteur) suggereren inderdaad dat leeftijd niet noodzakelijk lineair verband houdt met de ervaren werkkenmerken en de relatie tussen werkkenmerken, arbeidsvreugde en spanning lineair beïnvloedt. Bovendien is de categorische benadering volgens ons op dit ogenblik de enige mogelijke manier om na te gaan of het integrale JDR-model (met alle paden samen getoetst) verschilt in functie van leeftijd.

Wat theorieopbouw betreft, toont de huidige studie aan dat het JDR-model voor verschillende leeftijdsgroepen gehanteerd kan worden. Het lijkt ook te suggereren dat sommige werkkenmerken gemakkelijker aangepast kunnen worden dan andere. $\mathrm{Zo}$ is het niet denkbeeldig dat oudere werknemers maar weinig inspanningen moeten doen om meer autonomie te verwerven, misschien omdat bij leidinggevenden de impliciete veronderstelling heerst dat ouderen voldoende ervaring hebben om hun werk zelf te organiseren (Warr, 2007).

In dit artikel lag de focus op de hoofdeffecten van werkeisen en energiebronnen. $\mathrm{Er}$ is echter ook evidentie gevonden voor interactie-effecten. Volgens het JDR- 
Bert Schreurs, Anja Van den Broeck, Guy Notelaers, Beate van der Heijden \& Hans De Witte

model kunnen energiebronnen de negatieve invloed van werkeisen 'bufferen' en hoge werkeisen kunnen de relatie tussen hulpbronnen en optimaal functioneren versterken of 'boosten' (Bakker, Hakanen, Demerouti \& Xanthopoulou, 2007). Vervolgonderzoek zou kunnen nagaan in welke mate deze interactie-effecten tussen energiebronnen en werkeisen verschillen in functie van leeftijd.

\subsection{Conclusie}

Met dit onderzoek wilden we nagaan of oudere, jongere en werknemers uit de middengroep verschillen in de mate waarin ze bepaalde werkkenmerken ervaren, en of de relatie tussen werkkenmerken enerzijds en arbeidsvreugde en spanning anderzijds verschilt voor de drie leeftijdsgroepen. Samengevat bieden de huidige resultaten evidentie voor het selectiemechanisme van de Selectie-OptimalisatieCompensatie theorie (Baltes \& Dickson, 2001). Anderzijds vinden we maar weinig evidentie voor het optimalisatiemechanisme. Bovendien zijn de verschillen tussen de werknemers van verschillende leeftijdsgroepen beperkt. Dit wijst erop dat een HR-beleid dient te focussen op de ontwikkeling van een goede arbeidsinhoud voor alle werknemers. Meer bepaald pleiten we voor het voeren van een levensloopbewust personeelsbeleid (Nauta et al., 2010). Dit beleid dient gericht te zijn op het creëren van een goede match tussen de kenmerken van de baan en de behoeften van werknemers - bijvoorbeeld via job (re)design of job crafting waarbij de behoeften functie zijn van de levensfase van werknemers, eerder dan van leeftijd op zich.

\section{Praktijkbox}

- Organisaties doen er goed aan om een 'levensloopbewust' beleid te voeren. Een levensloopbewust beleid is erop gericht om de levensvraagstukken die werknemers in verschillende fasen van hun loopbaan bezighouden in kaart te brengen, eerder dan om het beleid af te stemmen op leeftijd op zich.

- Omdat behoeften van werknemers kunnen veranderen, in functie van loopbaanfase, doen organisaties er goed aan om werknemers hierover regelmatig (bijv. jaarlijks) te bevragen. Deze bevraging kan gebeuren in het kader van het jaarlijkse functioneringsgesprek, maar kan ook op een meer gestandaardiseerde wijze gebeuren, bijvoorbeeld via korte (online) vragenlijsten. Deze laatste methode heeft als voordeel dat niet alleen verschillen tussen groepen werknemers kunnen vastgesteld worden, maar dat ook veranderingen binnen individuen (over de tijd) aan het licht kunnen komen.

- Organisaties kunnen overwegen om oudere werknemers gebruik te laten maken van hun in de loop der jaren opgebouwde expertise, en om ze de mogelijkheid te geven een aantal hechte vriendschappelijke relaties te onderhouden op de werkvloer (eerder dan een groot netwerk te ontwikkelen), bijvoorbeeld door de rol van mentor of 'coach' op zich te nemen. 
- Organisaties doen er goed aan tijd en geld te investeren in het creëren van een gezonde en motiverende arbeidsinhoud, voor zowel jongere als oudere werknemers. Ouder worden staat immers niet gelijk met een bruuske verandering in het functioneren van werknemers, maar gaat in de regel gepaard met geleidelijke veranderingen waarop werknemers, eventueel met de hulp van hun werkgever, kunnen anticiperen of reageren door hun functie vorm te geven in overeenstemming met hun veranderende behoeften.

\section{Literatuur}

Ackerman, P.L. \& Rolfhus, E.L. (1999). The locus of adult intelligence: Knowledge, abilities, and nonability traits. Psychology and Aging, 14, 314-330.

Bakker, A.B. \& Demerouti, E. (2007). The Job Demands-Resources model: state of the art. Journal of Managerial Psychology, 22, 309-328.

Bakker, A.B., Demerouti, E. \& Schaufeli, W.B. (2003). Dual processes at work in a call centre: An application of the job demands-resources model. European Journal of Work and Organizational Psychology, 12, 393-417.

Bakker, A.B., Hakanen, J.J., Demerouti, E. \& Xanthopoulou, D. (2007). Job resources boost work engagement, particularly when job demands are high. Journal of Educational Psychology, 99, 274-284.

Bakker, A.B., Schaufeli, W.B., Leiter, M.P. \& Taris, T.W. (2008). Work engagement: An emerging concept in occupational health psychology. Work \& Stress, 22, 187-200.

Baltes, P.B. \& Dickson, M.W. (2001). Using life-span models in industrial-organizational psychology: The theory of selective optimization with compensation. Applied Developmental Science, 5, 51-62.

Beehr, T.A., Glazer, S., Nielson, N.L. \& Farmer, S.J. (2000). Work and nonwork predictors of employees' retirement ages. Journal of Vocational Behavior, 57, 206-225.

Berk, L.M. (2004). Development through the lifespan (3rd Ed.). Boston: Allyn and Bacon.

Boyd, C.M., Bakker, A.B., Pignata, S., Winefield, A.H., Gillespie, N. \& Stough, C. (2011). A longitudinal test of the job demands-resources model among Australian university academics. Applied Psychology: An International Review, 60, 112-140.

Carstensen, L.L. (2006). The influence of sense of time on human development. Science, 312.

Collins, G.A. (2003). Rethinking retirement in the context of an ageing workforce. Journal of Career Development, 30, 145-157.

Crawford, E.R., LePine, J.A. \& Rich, B.L. (2010). Linking job demands and resources to employee engagement and burnout: A theoretical extension and meta-analytic test. Journal of Applied Psychology, 95, 834-848.

Deci, E.L. \& Ryan, R.M. (2000). The "what" and "why" of goal pursuits: Human needs and the self-determination of behavior. Psychological Inquiry, 11, 227-268.

De Lange, A.H., De Witte, H. \& Notelaers, G. (2008). Should I stay or should I go? Examining longitudinal relations among job resources and work engagement for stayers versus movers. Work \& Stress, 22, 201-223. 
Bert Schreurs, Anja Van den Broeck, Guy Notelaers, Beate van der Heijden \& Hans De Witte

De Lange, A.H., Taris, T.W., Jansen, P., Kompier, M., Houtman, I. \& Bongers, P. (2005). Werk en motivatie om te leren: zijn er verschillen tussen jongere en oudere werknemers? Gedrag \& Organisatie, 18, 309-325.

De Lange, A.H., Taris, T.W., Jansen, P., Kompier, M., Houtman, I. \& Bongers, P. (2010). On the relationships among work characteristics and learning-related behavior: Does age matter? Journal of Organizational Behavior, 31, 925-950.

De Lange, A.H., Taris, T.W., Jansen, P.G.W., Smulders, P., Houtman, I.L.D. \& Kompier, M.A.J. (2006). Age as a factor in the relation between work and mental health: results from the longitudinal TAS survey. In: J. Houdmont \& S. McIntyre (Eds.), Occupational Health Psychology: European Perspectives on Research, Education and Practice (Vol. 1, pp. 21-45). Maia, Portugal: ISMAI Publications.

Demerouti, E., Bakker, A.B., Nachreiner, F. \& Schaufeli, W.B. (2001). The job demandsresources model of burnout. Journal of Applied Psychology, 86, 499-512.

Edwards, J.R. \& Rothbard, N.P. (2000). Mechanisms linking work and family: Clarifying the relationship between work and family constructs. Academy of Management Review, 25, 178-199.

Eurostat (2010, januari). Employment rate of older workers. Gedownload op 17 maart 2010 van Eurostat: http://epp.eurostat.ec.europa.eu/portal/page/portal/product_details/ dataset?p_product_code=TSDDE100.

Finkelstein, L.M. \& Farrell, S.K. (2007). An expanded view of age bias in the workplace. In K.S. Schultz \& G.A. Adams (Eds.), Aging and work in the $21^{\text {st }}$ century (pp. 73-108). Mahwah, NJ: Lawrence Erlbaum Associates.

Fouad, N.A. \& Arbona, C. (1994). Careers in a cultural context. Career Development Quarterly, 43, 96-104.

Freund, A.M. \& Baltes, P.B. (1998). Selection, optimization, and compensation as strategies of life management: Correlations with subjective indicators of successful aging. Psychology and Aging, 13, 531-543.

Greller, M.M. \& Stroh, L.K. (1995). Careers in midlife and beyond: A fallow field in need of sustenance. Journal of Vocational Behavior, 47, 232-247.

Hakanen, J.J., Bakker, A.B. \& Schaufeli, W.B. (2006). Burnout and work engagement among teachers. Journal of School Psychology, 43, 495-513.

Hakanen, J.J., Schaufeli, W.B. \& Ahola, K. (2008). The Job Demands-Resources model: A three-year cross-lagged study of burnout, depression, commitment, and work engagement. Work \& Stress, 22, 224-241.

Halbesleben, J.R.B. \& Buckley, M.R. (2004). Burnout in organizational life. Journal of Management, 30, 859-879.

Hobfoll, S.E. (1989). Conservation of resources: A new attempt at conceptualizing stress. American Psychologist, 44, 513-524.

Hoffman, B.J. \& Woehr, D.J. (2009). Disentangling the meaning of multisource performance rating source and dimension factors. Personnel Psychology, 62, 735-765.

Hoijtink, H.J.A. \& De Jonge, J. (2007). Beginselen van covariantie-structuuranalyse. Gedrag \& Organisatie, 20, 57-81.

Hu, L. \& Bentler, P.M. (1999). Cutoff criteria for fit indexes in covariance structure analysis: Conventional criteria versus new alternatives. Structural Equation Modeling, 6, $1-55$.

Jex, S.M., Wang, M. \& Zarubin, A. (2007). Aging and occupational health. In K.S. Schultz \& G.A. Adams (Eds.), Aging and work in the 21st century (pp. 199-223). Mahwah, NJ: Lawrence Erlbaum Associates. 
Kooij, D., De Lange, A., Jansen, P. \& Dikkers, J. (2008). Older workers' motivation to continue to work: five meanings of age. A conceptual review. Journal of Managerial Psychology, 23, 364-394.

Kooij, D., De Lange, A.H., Jansen, P.G.W., Kanfer, R. \& Dikkers, J.S. (2011). Age and workrelated motives: results of a meta-analysis. Journal of Organizational Behavior, 32, 197-225.

Kooij, D., Jansen, P.G.W., Dikkers, J.S. \& De Lange, A.H. (2010). The influence of old age on the association between HR practices and individual worker outcomes: A metaanalysis. Journal of Organizational Behavior, 31, 1111-1136.

Kristof-Brown, A.L., Zimmerman, R.D. \& Johnson, E.C. (2005). Consequences of individuals' fit at work: A meta-analysis of person-job, person-organization, person-group, and person-supervisor fit. Personnel Psychology, 58, 281-342.

Lang, F.R. \& Carstensen, L.L. (2002). Time counts: Future time perspective, goals, and social relationships. Psychology and Aging, 17, 125-139.

Levinson, D. (1986). A conception of adult development. American Psychologist, 41, 3-13.

Lewig, K.A., Xanthopoulou, D., Bakker, A.B., Dollard, M.F. \& Metzer, J.C. (2007). Burnout and connectedness among Australian volunteers: A test of the Job Demands-Resources model. Journal of Vocational Behavior, 71, 429-445.

Lindenberger, U. \& Baltes, P.B. (1994). Sensory functioning and intelligence in old age: A strong connection. Psychology and Aging, 9, 339-355.

Matthews, R.A., Bulger, C.A. \& Barnes-Farrell, J.L. (2010). Work social supports, role stressors, and work-family conflict: The moderating effect of age. Journal of Vocational Behavior, 76, 78-90.

Mayes, B.T., Barton, M.E. \& Ganster, D.C. (1991). An exploration of the moderating effect of age on job stressor-employee strain relationships. Journal of Social Behavior \& Personality, 6, 289-308.

McArdle, A., Vasilaki, A. \& Jackson, M. (2002). Exercise and skeletal muscle ageing: cellular and molecular mechanisms Aging Research Reviews, 1, 79-93.

Mullan, C. \& Gorman, L. (1972). Facilitating adaptation to change: A case study in retraining middle-aged and older workers at Aer Lingus. Industrial Gerontology, 12, 20-39.

Nauta, A., De Lange, A.H. \& Görtz, S. (2010). Lang zullen ze leven, werken en leren. Een schema voor het begrijpen en beïnvloeden van inzetbaarheid gedurende de levensloop. Gedrag \& Organisatie, 23, 136-157.

Niessen, C., Swarowsky, C. \& Leiz, M. (2010). Age and adaptation to changes in the workplace. Journal of Managerial Psychology, 25, 356-383.

Parker, S.K., Wall, T.D. \& Cordery, J.L. (2001). Future work design research and practice: Towards an elaborated model of work design. Journal of Occupational and Organizational Psychology, 74, 413-440.

Podsakoff, P.M., MacKenzie, S.B., Lee, J. \& Podsakoff, N.P. (2003). Common method bias in behavioral research: A critical review of the literature and recommended remedies. Journal of Applied Psychology, 88, 879-903.

Salthouse, T.A. (1996). The processing-speed theory of adult age differences in cognition. Psychological Review, 103, 403-428.

Schalk, R., Van Veldhoven, M., De Lange, A.H., De Witte, H., Kraus, K. Stamov-Rossnagel, C. et al. (2010). Moving European research on work and ageing forward: Overview and agenda. European Journal of Work and Organizational Psychology, 19, 76-101.

Schaufeli, W.B. \& Bakker, A.B. (2004). Job demands, job resources, and their relationship with burnout and engagement: a multi-sample study. Journal of Organizational Behavior, 25, 293-315. 
Bert Schreurs, Anja Van den Broeck, Guy Notelaers, Beate van der Heijden \& Hans De Witte

Schaufeli, W.B., Bakker, A.B. \& Van Rhenen, W. (2009). How changes in job demands and resources predict burnout, work engagement, and sickness absenteeism. Journal of Organizational Behavior, 30, 893-917.

Schreurs, B., Van Emmerik, IJ.H., De Cuyper, N., Notelaers, G. \& De Witte, H. (2011). Job demands-resources and early retirement intention: Differences between blue- and white-collar workers. Economic and Industrial Democracy, 32, 47-68.

Schultz, K.S. \& Adams, G.A. (2007). Aging and work in the 21st century. Mahwah, NJ: Lawrence Erlbaum Associates.

Schultz, K.S., Morton, K.R. \& Weckerle, J.R. (1998). The influence of push and pull factors on voluntary and involuntary early retirees' retirement decision and adjustment. Journal of Vocational Behavior, 53, 45-57.

Spillman, B.C. \& Pezzin, L.E. (2000). Potential and active family caregivers: Changing networks and the 'sandwich generation'. Milbank Quarterly, 78, 347-374.

Super, D.E. (1984). Career and life development. In D. Brown \& L. Brooks (Eds.), Career choice and development (pp. 192-234). San Francisco: Jossey-Bass.

Thijssen, J.G.L. \& Van der Heijden, B.I.J.M. (2003). Evaporated talent? Problems with talent development during the career. International Journal of Human Resources Development and Management, 3, 154-170.

Van den Broeck, A., De Cuyper, N., De Witte, H. \& Vansteenkiste, M. (2010). Not all demands are equal: Differentiating job hindrances and job challenges in the Job Demands-Resources model. European Journal of Work and Organizational Psychology, 19, 735-759.

Van den Broeck, A., Vansteenkiste, M., De Witte, H. \& Lens, W. (2008). Explaining the relationships between job characteristics, burnout, and engagement: The role of basic psychological need satisfaction. Work \& Stress, 22, 277-294.

Van der Heijden, B.I.J.M. (2006). Age differences in career activities among higher-level employees in the Netherlands: A comparison between profit sector and non-profit sector staff. International Journal of Training and Development, 10, 98-120.

Van der Heijden, B.I.J.M., De Lange, A.H., Demerouti, E. \& Van der Heijde, C.M. (2009). Age as moderator in the relationship between self- versus supervisor ratings of employability and career success. Journal of Vocational Behavior, 2, 156-164.

Van Emmerik, IJ.H., Jawahar, I.M., Schreurs, B. \& De Cuyper, N. (2011). Social capital, team efficacy and team potency: The mediating role of team learning behaviors. Career Development International, 16, 82-99.

Van Maanen, J. (1975). Breaking in: Socialization to work. In R. Dubin (Ed.), Handbook of work, organization and society (pp. 67-120). Chicago: Rand McNally.

Van Veldhoven, M.J.P.M., Meijman, T. \& Broersen, S. (2002). Handleiding VBBA: onderzoek naar de beleving van psychosociale arbeidsbelasting en werkstress met behulp van de vragenlijst beleving en beoordeling van de arbeid. Amsterdam: Stichting Kwaliteitsbevordering Bedrijfsgezondheidszorg.

Voka-Kenniscentrum (2009, december). Pensioenen: de weg vooruit. Eindrapport van de Werkgroep Pensioenen. Vlaams Economisch Verbond.

Warr, P. (2007). Work, happiness and unhappiness. Mahwah, NJ: Lawrence Erlbaum Associates.

Warr, P. (2008). Work values: Some demographic and cultural correlates. Journal of Occupational and Organizational Psychology, 81, 751-775.

Weiss, E.M. \& Maurer, T.J. (2004). Age discrimination in personnel decisions: A re-examination. Journal of Applied Social Psychology, 34, 1551-1562.

Wright, J.D. \& Hamilton, R.F. (1978). Work satisfaction and age: Some evidence for the 'job change' hypothesis. Social Forces, 56, 1140-1157. 
Xanthopoulou, D., Bakker, A.B., Demerouti, E. \& Schaufeli, W.B. (2009). Work engagement and financial returns A diary study on the role of job and personal resources. Journal of Occupational and Organizational Psychology, 82, 183-200.

Yeatts, D.E., Folts, W.E. \& Knapp, J. (2000). Older workers' adaptation to a changing workplace: Employment issues for the 21st century. Educational Gerontology, 26, 565-582.

\section{The relationship between job demands, job resources, strain, and work enjoyment: a matter of age?}

Bert Schreurs, Anja Van den Broeck, Guy Notelaers, Beate van der Heijden \& Hans De Witte, Gedrag \& Organisatie, volume 25, March 2011, nr. 1, pp. 5-27.

Drawing on the Selection-Optimization-Compensation theory and the Job Demands-Resources model this study addresses the following research questions: (1) are there mean differences in the perceived levels of particular job characteristics between employees from different age groups; and (2) to what extent does the relationship between job characteristics and work outcomes (i.e., job strain and work enjoyment) differ across age groups? Data were collected from a sample of 15,464 employees, of which 3,850 were younger than 35 (young group), 7,273 were between 36 and 45 (middle group), and 4,341 were older than 45 (old group). Significant age differences were found in the levels of job characteristics: Young employees are most positive about their relationships with their colleagues and direct supervisor, and report to have the lowest levels of workload; employees from the middle group report to have the highest levels of role conflict; employees from the oldest age group perceive to have the highest levels of autonomy, and perceive more than other employees to be confronted with hindering changes at work. In addition, the strength of the relationship between job characteristics and work outcomes differed across age groups, although differences were rather small. From this we conclude that HR management should focus on creating high-quality jobs for all employees, young and old.

Key-words: age, older employees, psychological job characteristics, Job DemandsResources model, life cycle, Selection Optimization-Compensation theory 